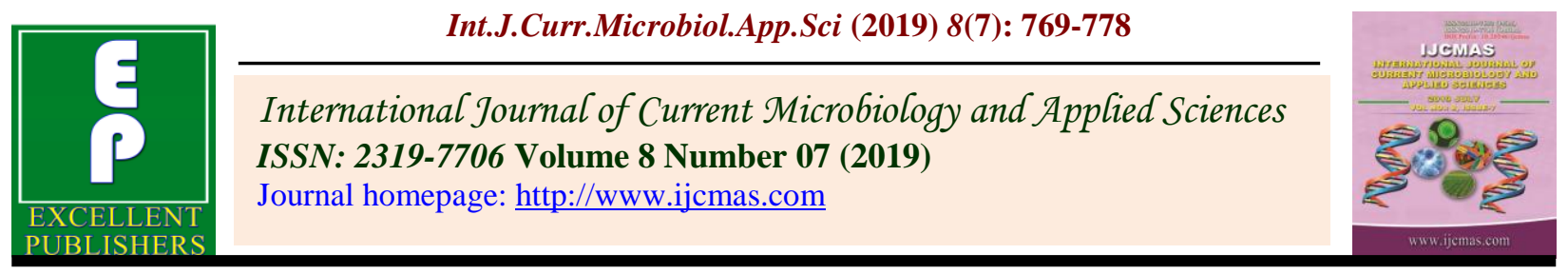

Original Research Article

https://doi.org/10.20546/ijcmas.2019.807.093

\title{
Knowledge, Attitude and Effect on Farm Women Regarding ICTs in the District of West Garo Hills, Meghalaya, India
}

\author{
Puspita Das* and Nikrachi Ch. Sangma
}

Department of Extension and Communication Management, College of Community Science, Central Agricultural University, Sangsanggre, Tura, Meghalaya, India

*Corresponding author

\section{A B S T R A C T}

\section{Keywords}

Knowledge,

Attitude, Effect, ICTs

\section{Article Info}

Accepted:

07 June 2019

Available Online:

10 July 2019
This paper identified their knowledge level of different ICTs in agriculture and allied sectors, their attitude towards different ICTs and their perceived effect of ICTs in agriculture and allied sectors. The study was conducted in the district of West Garo Hills, Meghalaya. A total of hundred samples were collected for the present study and was studied between March 2018 and May 2019. The results revealed that large percentage $(81 \%)$ of the respondents have use mobile phones. According to their awareness level large percentage of the respondents were aware and use mobile to call and to send SMS to others. Apart from their awareness on use and send SMS only few (2\%) percentage of the respondents were connected to internet services. Their attitude towards ICT were favourable so they need to encourage little more by the ICT expertise providing them a short duration training or awareness programme on the use and importance of ICTs. This will help them to learn a valuable of ICTs in a different way of agriculture and allied activities. It was found that the correlation between age and the attitude towards ICT of respondents is negligible because the attitude towards ICTs does not depend on age. So, their effect towards ICT is negligible. So far to their perceived effects towards ICTs and socio-economic variables were moderately correlated because the respondents whose education, mass media exposure, ownership of mobile phones is higher than their attitude towards ICT is more positive.

\section{Introduction}

ICT are technologies offering new ways for communicating and exchanging information and knowledge. The phrase ICT was coined by Stevenson in 1997. ICT is a term which is currently used to denote a wide range of services, applications and technologies using various types of equipment and software, often running over telecommunication network. ICT can be broadly understood as the technologies that facilitates communication by electronic means. It includes a range of technologies starting from radio, television, telephone up to modern technologies like mobile phone, multimedia, internet and satellite-based communication systems. Information refers to the patterned matter energy that affects the probabilities available to an individual making decision. It is one of 
the most aspired fields in today's world. In recent years there is a visible shift from the old ways of delivering information to the modern ways of information delivery systems, while ICT is gaining prominence as an engine for economic growth. India has surfaced as a country with a sound foothold in the field of ICT.

ICT plays an important role when people try to overcome the limitations of time and distance to communicate, exchange information or work together. There are various technologies that play a role in that process, technologies that are used to establish communication over a distance (telecommunication) and technologies that are used to store, process and provide data information technology. The convergence of telecommunication and computer technology has resulted in what is called information and communication technology (ICT). ICT is a general term used to describe a large number of different technologies and applications.

The importance of ICT is not the technology as such, but it's enabling function in access to knowledge, information and communications, which are important elements in today's economic and social interactions. ICT particularly the internet is transforming all human activities dependent on information, including rural development and in other areas. Internet is cost effective, powerful, decentralized and it is in the hands of civil society who can share knowledge and information access to operate efficiently in a dynamic global environment. The existing transfer of technology mechanisms and extension programs mostly government run is either slow or ineffective in bridging the linkages between the research community and the farmers. ICT cannot only strengthen the traditional channels of information dissemination but also create new ones that allow localization of content rich information products and services and their real time delivery through multiple channels.

India has not lagged behind in the use of ICT to provide the required information to the farmers. A beginning was made in the use of ICT with the designing of Financial Accounting Information System in 1971 by Jute Corporation of India covering seven states viz., Andhra Pradesh, Assam, Bihar, Meghalaya, Orissa, Tripura and West Bengal. Later many projects like Information Village Centre, Gyandoot Project, e-Choupal, egrama, etc came into existence. Today it is possible to find a solution to present problems of farmers by using the potential of information and communication technologies to meet the location specific needs of the farmers. The information and communication networks are expanding very fast. The developed nations are using laser technology instead of tractors to plough lands. This helps in optimising the use of various inputs such as water, seeds, fertilizers, etc. the problem in Indian farmers cannot afford this technology and unless government comes in support for agriculture infrastructure. The agriculture information is vast, interdisciplinary and specific to different agro-climatic zones and needs a proper information dissemination system for its effective use. Hence, agriculture information resources should be significantly organised and processed to disseminate right information to the right user at the right time. Communication is recognised as an important input for development to disseminate and create dialogue among different stakeholders about the technologies and issues of agriculture, environment and sustainable development.

The following objectives as per the research topic are given as:

To study background profile of the respondents. 
To conduct situational analysis on knowledge of ICT in agriculture and allied sectors.

To explore the acquired attitude towards ICT

To identify the perceived effects of ICT.

\section{Materials and Methods}

The study was conducted in the district of West Garo Hills, Meghalaya. Three villages were selected randomly from one block of West Garo Hills, Meghalaya.

The data was collected from 100 farm women of selected villages. The interview scheduled was prepared regarding knowledge of ICT. The data was collected in the month of May to June 2018.

\section{Results and Discussion}

Age

From figure 1, it is clearly indicates that large percentage $(59 \%)$ of the respondents belonged to young age (18-35 years) and the least percentage $(10 \%)$ of the respondents belonged to upper middle age (51 years and above). The finding shows that middle age group were more in number than upper middle age group.

\section{Caste}

It is revealed from the findings that the entire respondents were belonged to Scheduled tribe because the state of Meghalaya was dominated by tribal people.

\section{Education}

From figure 2 indicates that large percentage $(39 \%)$ of the respondents have their education up to class X followed by 22 percent are able to read and write whereas only 1 per cent each of the respondents have education up to graduation and post-graduation. The finding shows that respondents studied up to class $\mathrm{X}$ were more in number compared to other educational qualification.

\section{Marital status}

From figure 3 indicates that large percentage $(83 \%)$ of the respondents were married followed by 15 per cent of the respondents belonged to unmarried and 1 per cent each of the respondents were widow and divorcee.

\section{Occupation}

\section{Main occupation}

From figure 4 it is observed that 47 per cent of the respondents belonged to daily wage earner followed by 36 per cent of the respondents belonged to farming and 17 per cent of the respondents were engaged in government service.

The finding shows that main occupation of the respondents was predominantly from daily wage earner.

\section{Subsidiary occupation}

From figure 5, it reveals that 56 per cent of the respondents have farming as their subsidiary occupation followed by 39 per cent of the respondents, daily wage earner and only 5 per cent of the respondents were engaged in government service. The finding shows that subsidiary occupation of the respondents was predominated by farming.

\section{Type of family}

It is revealed from the findings that entire respondents were belonged to nuclear family. This may so happen due to the tradition of separation of daughter after marriage in a matrilineal society. 
Table.1 Distribution of respondents according to their mass media ownership and Frequency of use

\begin{tabular}{|c|c|c|c|c|c|c|}
\hline \multirow[t]{2}{*}{ Mass media } & \multirow{2}{*}{$\begin{array}{l}\text { Owned } \\
\%\end{array}$} & \multirow[b]{2}{*}{$\begin{array}{c}\text { Other } \\
\text { Source } \\
\text { (use owned } \\
\text { by others) } \\
\%\end{array}$} & \multicolumn{4}{|c|}{ Frequency of use } \\
\hline & & & Always & Sometimes & Rarely & Never \\
\hline Radio & 3 & 97 & 3 & - & - & 97 \\
\hline Television & 34 & 66 & 34 & - & 16 & 50 \\
\hline News paper & 11 & 89 & - & - & 30 & 70 \\
\hline Magazines & 11 & 89 & - & - & 28 & 72 \\
\hline $\begin{array}{l}\text { Others (Journals, } \\
\text { leaflets, booklets etc.) }\end{array}$ & 8 & 92 & - & - & 22 & 78 \\
\hline
\end{tabular}

Table.2 Percent distribution of respondents according to their awareness \& use of different ICT tools \& services

\begin{tabular}{|c|c|c|c|c|}
\hline \multirow[t]{2}{*}{ ICT tools and services } & \multicolumn{2}{|c|}{ Aware } & \multicolumn{2}{|c|}{ Use } \\
\hline & Yes & No & Yes & No \\
\hline \multicolumn{5}{|l|}{ Mobile without internet } \\
\hline Calling & 79 & 19 & 79 & 19 \\
\hline SMS & 79 & 19 & 79 & 19 \\
\hline Memory stick & 72 & 22 & 21 & 77 \\
\hline Any other & - & 100 & - & 100 \\
\hline \multicolumn{5}{|l|}{ Mobile with internet } \\
\hline Calling & 2 & - & 2 & - \\
\hline SMS ing & 2 & - & 2 & - \\
\hline Memory stick/ Memory card & 2 & - & 2 & - \\
\hline WhatsApp & 2 & - & 0 & - \\
\hline Facebook & 2 & - & 2 & - \\
\hline Games/ movies/ songs & 2 & - & 2 & - \\
\hline Accessing different internet sites & 2 & - & 2 & - \\
\hline Any other & 0 & - & 0 & - \\
\hline \multicolumn{5}{|l|}{ Computer /laptop without internet } \\
\hline Office documents/presentations etc. & - & - & - & - \\
\hline Any other & - & - & - & - \\
\hline \multicolumn{5}{|l|}{ Computer/laptop with internet } \\
\hline Office documents/presentations etc. & - & - & - & - \\
\hline Facebook, social media & - & - & - & - \\
\hline Accessing different internet sites & - & - & - & - \\
\hline Any other & - & - & - & - \\
\hline
\end{tabular}


Table.3 Percent distribution of respondents according to their attitude towards ICTs

\begin{tabular}{|c|c|c|c|c|c|c|}
\hline Statements & SA & $\mathbf{A}$ & UD & $\mathbf{D}$ & SD & $\begin{array}{l}\text { Mean } \\
\text { score }\end{array}$ \\
\hline $\begin{array}{l}\text { I feel updated whenever using ICTs to find any } \\
\text { information }\end{array}$ & 3 & 18 & 37 & 38 & 4 & IV \\
\hline Use of ICTs is a wastage of time & 10 & 31 & 33 & 22 & 4 & $\mathrm{XI}$ \\
\hline ICTs helps the farmers in decision making & - & 2 & 46 & 47 & 5 & $\mathrm{X}$ \\
\hline Use of ICTs makes life more complicated & - & 27 & 44 & 22 & 7 & III \\
\hline ICTs improves the farmers output & - & 1 & 65 & 30 & 4 & VII \\
\hline ICTs helps farmers to acquire needed knowledge & - & 1 & 63 & 34 & 2 & VII \\
\hline Sever as a link between government and farmers & - & 1 & 65 & 33 & 1 & VI \\
\hline ICTs motivate farmers to adopt new technology & - & 1 & 62 & 35 & 2 & VIII \\
\hline $\begin{array}{l}\text { ICTs demonstrate improved technologies to } \\
\text { farmers }\end{array}$ & - & 1 & 62 & 35 & 2 & VIII \\
\hline $\begin{array}{l}\text { Use of ICTs creates isolation from the other } \\
\text { population }\end{array}$ & - & & 61 & 37 & 2 & IX \\
\hline $\begin{array}{l}\text { I feel proud to be able to access the internet at any } \\
\text { time }\end{array}$ & - & 1 & 92 & 5 & 1 & II \\
\hline $\begin{array}{l}\text { ICTs connect people with latest trends of } \\
\text { technology }\end{array}$ & - & 1 & 77 & 20 & 2 & $\mathrm{~V}$ \\
\hline Any other & - & 1 & 98 & 2 & - & I \\
\hline
\end{tabular}

* SA-Strongly Agree, A-Agree, UD- Un-decided, D-Disagree, SD-Strongly disagree

Table.4 Overall attitude of respondents towards ICT

\begin{tabular}{|l|c|c|c|c|c|}
\hline Category & Score range & Frequency & Percentage & Mean & SD \\
\hline $\begin{array}{l}\text { Highly } \\
\text { favourable }\end{array}$ & $40.5-43$ & 8 & $8 \%$ & 42 & 0.534 \\
\hline Favourable & $31.1-40.5$ & 72 & $72 \%$ & 37.15 & 2.704 \\
\hline $\begin{array}{l}\text { Least } \\
\text { favourable }\end{array}$ & $19-31.1$ & 20 & $20 \%$ & 28.45 & 2.781 \\
\hline
\end{tabular}


Table.5 Distribution of respondents according to their perceived effects of ICTs on improving information access

\begin{tabular}{|l|c|c|c|c|}
\hline Effects & \multicolumn{2}{|c|}{ Yes } & \multicolumn{2}{c|}{ No } \\
\hline Enhanced timely feedback & Frequency & Percentage & Frequency & Percentage \\
\hline Reduced male-female digital divide & - & - & 100 & 100 \\
\hline Improves quality of information & - & - & 100 & 100 \\
\hline Improves access to agricultural inputs & - & 6 & 94 & 94 \\
\hline Reduces rural-urban digital divide & - & - & 100 & 100 \\
\hline Improves cultural compatibility of & - & - & 100 & 100 \\
\hline agricultural issues & - & - & 100 & 100 \\
\hline Improves record keeping & - & - & 100 & 100 \\
\hline Enhances timeliness of information & - & - & 100 & 100 \\
\hline Improves information seeking behaviour & 2 & 2 & 98 & 100 \\
\hline Increases the information flow & - & - & 100 & 100 \\
\hline $\begin{array}{l}\text { Improves awareness of agricultural events } \\
\text { and news }\end{array}$ & - & - & 91 & 91 \\
\hline Enhances accuracy of information & 6 & 6 & 94 & 94 \\
\hline Helps in data sharing and dissemination & 6 & 6 & 94 & 94 \\
\hline Increases General Knowledge & 6 & 6 & 94 & 94 \\
\hline Helpful in learning concept & 2 & 2 & 98 & 98 \\
\hline Improves reading habits & - & - & 100 & 100 \\
\hline Improves working habits & - & - & 100 & 100 \\
\hline $\begin{array}{l}\text { Helpful in collecting lot of information within } \\
\text { time }\end{array}$ & & & & 19 \\
\hline Reduce the need of face to face meetings & 81 & 81 & 19 & 10 \\
\hline Helpful in time saving & 63 & 63 & 37 & 37 \\
\hline Any other & - & - & 100 & 100 \\
\hline
\end{tabular}

Table.6 Correlation between personal and socio-economic variables of the respondents with attitude towards ICT

\begin{tabular}{|l|c|}
\hline Variables & Correlation coefficient \\
\hline Age & 0.032 \\
\hline Education & -0.177 \\
\hline Occupation & -0.229 \\
\hline Family Income & -0.028 \\
\hline Organisational membership & -0.020 \\
\hline Organizational participation & -0.066 \\
\hline Extension contact & -0.221 \\
\hline Mass media exposure & -0.101 \\
\hline Ownership of Mobile phones & -0.282 \\
\hline
\end{tabular}


Table.7 Correlation between personal and socio-economic variables of the respondents with perceived effects of ICTs

\begin{tabular}{|l|c|}
\hline Variables & Correlation coefficient \\
\hline Age & 0.041 \\
\hline Education & 0.459 \\
\hline Occupation & 0.485 \\
\hline Family Income & 0.207 \\
\hline Organisational membership & 0.152 \\
\hline Organizational participation & 0.027 \\
\hline Extension contact & -0.064 \\
\hline Mass media exposure & 0.434 \\
\hline Ownership of Mobile phones & 0.449 \\
\hline
\end{tabular}

Table.8

\begin{tabular}{|l|l|l|}
\hline Category & Frequency & Percentage \\
\hline Member & 62 & $62 \%$ \\
\hline Office Bearer & 14 & $14 \%$ \\
\hline
\end{tabular}

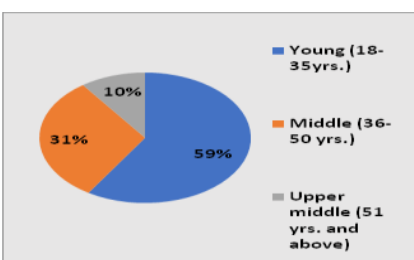

Fig.1 Distribution of respondents according to their age

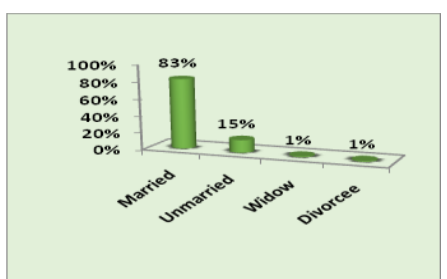

Fig.3 Distribution of respondents according to their marital status

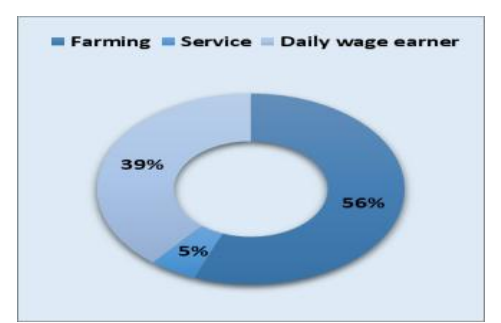

Fig.5 Distribution of respondents according to their Subsidiary occupation

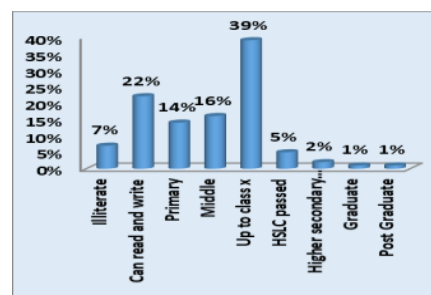

Fig.2 Distribution of respondents according to their educational qualification

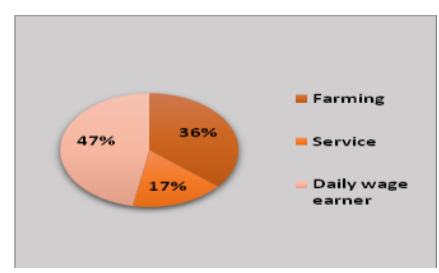

Fig.4 Distribution of respondents according to their main occupation

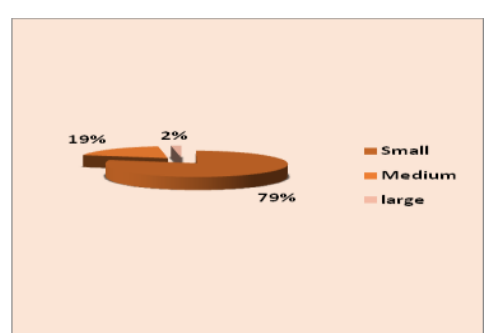

Fig.6 Distribution of respondents according to their family size 


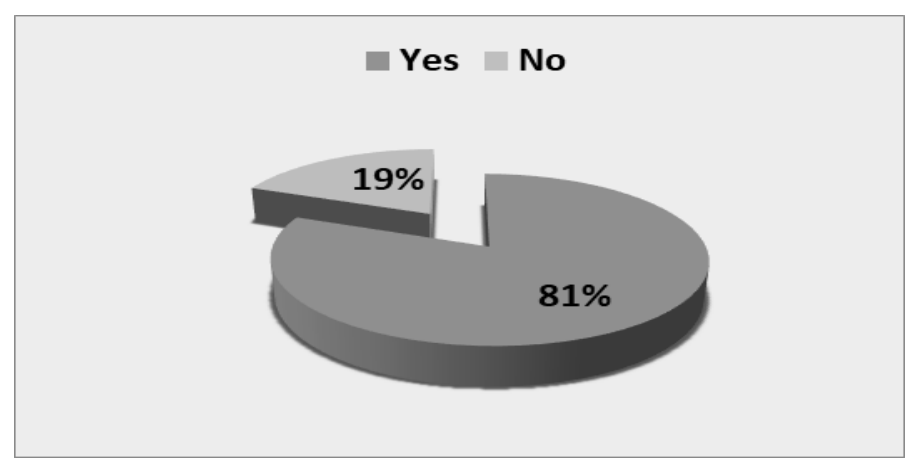

Fig.7 Distribution of respondents according to their ownership of mobile

\section{Size of family}

From figure 6 indicates that large percentage (79\%) of the respondents belonged to small family (2-4) followed by 19 per cent belonged to medium family (4-6) and 2 per cent belong to large family. It was found that all the respondents belonged to nuclear families so their family sizes are small and medium.

\section{Organizational participation}

From table 8 reflects that 62 per cent of the respondents were members in various organisations but only 14 per cent of the respondents were office bearer in any organisation like SHGs, Anganwadi centres, etc.

\section{Type of membership}

Table 1 indicates that 34 per cent of the respondents have television at their own followed by 11 per cent each in newspaper and magazines, 8 percent in others (Journals, leaflets, booklets etc.) and only 3 per cent in radio whereas 97 per cent of the respondents does not have radio at their own followed by 92 per cent in others (Journals, leaflets, booklets etc.), 89 per cent each in newspaper and magazines and 66 per cent in television. The frequency of use of television was more in number than other mass media.

\section{Ownership of mobile}

From figure 7 it is clearly indicates that 81 per cent of the respondents have use mobile phones whereas only 19 per cent of the respondents does not have mobile because some respondents they cannot afford it due to lack of financial problems and few respondents they don't need it and only few respondents they use common mobile phone.

From table 2 it is clearly indicates that 79 per cent of the respondents were aware and use mobile to call and to send SMS to others while 72 per cent were aware about memory stick which is use in mobile but only few $(21 \%)$ respondents use memory stick in their mobile. Whereas only 2 per cent were aware and use mobile with internet service to stay connected with friends and relatives.

From Table 3, it is clearly revealed that respondents vary in their attitude towards ICTs and are placed in a different ranking order. The attitude such as any other, I feel proud to be able to access the internet at any time, use of ICTs make life more complicated, I feel updated whenever using ICTs to find any information and ICTs connect people with latest trends of technology were found in higher rank. Whereas the attitude towards ICTs such as serve as a link between government and farmers, ICTs improves the farmers output, 
ICTs helps farmers to acquire needed knowledge, ICTs motivate farmers to adopt new technology, ICTs demonstrate improved technologies to farmers, Use of ICTs creates isolation from the other population, ICTs helps the farmers in decision making were found in lower rank. The findings clearly show that respondents were not aware about use and importance of ICTs.

From Table 4, it is clearly revealed that respondents were attained favourable attitude towards ICT. It is encouraging to know that a sizeable percentage $(20 \%)$ of the respondents showed least favourable towards ICT followed by a small percentage (8\%) that showed highly favourable attitude towards ICT. Since a large percentage $(72 \%)$ of the respondents had favourable attitude towards ICT so they need to encourage little more by the ICT expertise providing them a short duration training or awareness programme on the use and importance of ICTs. This will help them to learn a valuable of ICTs in a different way of agriculture and allied activities.

From Table 5, it reveals that 81 per cent of the respondents feel that using mobile reduce the need of face to face meeting in a short duration while 63 per cent of the respondents find helpful in time saving whereas 100 per cent of the respondents does not get benefitted in improves working habits, awareness of agricultural events and news, information seeking behaviour and so on.

From Table 6, it was found that the correlation between age and the attitude towards ICT of respondents is negligible because the attitude towards ICT does not depend on age. Whereas the socio-economic variables (namely; education, occupation, family income, organisational memberships, organisational participation, extension contact, mass media exposure, ownership of mobiles) were weak negatively correlated because all the mentioned variables have no positive effects towards ICT. So, their effect towards ICT is negligible.

From Table 7, it was found that the attitude towards ICT does not depend on age because the perceived effects towards ICT are independent of age. The perceived effects towards ICT and socio-economic variables (namely; education, occupation, mass media exposure, ownership of mobile phones) were moderately correlated because the respondents whose education, mass media exposure, ownership of mobile phones is higher than their attitude towards ICT is more positive. Whereas the perceived effects of ICTs towards the socio-economic variables (namely; family income, organisational memberships) were weakly correlated because the positive perceived effects towards ICT does not depends on income level and organisational memberships.

From the study it can be concluded that large percentage $(81 \%)$ of the respondents have use mobile phones whereas only few (19\%) respondents does not have mobile phones because some respondents they cannot afford it due to lack of financial problems and few respondents they don't need it and only few respondents they use common mobile phones. According to their awareness level large percentage of the respondents were aware and use mobile to call and to send SMS to others.

Apart from their awareness on use and send SMS only few (2\%) percentage of the respondents were connected to internet services. Their attitude towards ICT were favourable so they need to encourage little more by the ICT expertise providing them a short duration training or awareness programme on the use and importance of ICTs. This will help them to learn a valuable of ICTs in a different way of agriculture and 
allied activities.

It was found that the correlation between age and the attitude towards ICT of respondents is negligible because the attitude towards ICTs does not depend on age. So, their effect towards ICT is negligible. So far to their perceived effects towards ICTs and socioeconomic variables were moderately correlated because the respondents whose education, mass media exposure, ownership of mobile phones is higher than their attitude towards ICT is more positive.

\section{References}

Bell, P., Reddy, P. and Rainies, L. (2004), "Rural Areas and the Internet. Rural Americans' Internet use has grown, but they continue to lag behind others", Pee Internet \& American Life Project, Retrieved http://www.pewtrusts.org/news_room_d etail.aspx? Id=17062.

Bhatnagar S. and Vyas N. (2001). Gyandoot: Community-Owned Rural Internet Kiosks, EGovernment Case Studies,
World Bank, Washington, DC. Retrieved from www.worldbank.org/ publicsector/egov/gyandootcs.htm.

Bouwman H. Etal (2005). Information and Communication Technology in Organisations. Sage Publications. 22.

Essays, UK. (November 2018). Role of ICT in Research Information Technology Essay. Retrieved from https://www.ukessays.com/essays/infor mation-technology/role-of-ict-inresearch-information-technologyessay.php?vref=1

http://www.businessplannigeria.com.ng/infor mation-communication-technology-ict/

Raghuprasad K. P., Devaraja S.C and Gopala Y. M. (2013). An Analysis of Knowledge Level of Farmers on Utilisation of ICT Tools for Farm Communication. Journal of Rural Development, Vol. 32, No. (3) pp. 301 310 NIRD, Hyderabad.

Sarkar, J. (2019). Information and Communication technology: Internet. https://www.researchgate.net/publicatio n/265142588_Information_and_Commu nication_technology_Internet

\section{How to cite this article:}

Puspita Das and Nikrachi Ch. Sangma. 2019. Knowledge, Attitude and Effect on Farm Women Regarding ICTs in the District of West Garo Hills, Meghalaya, India. Int.J.Curr.Microbiol.App.Sci. 8(07): 769-778. doi: https://doi.org/10.20546/ijcmas.2019.807.093 